\title{
Worker-Specific Effects of Globalisation
}

\author{
Hartmut Egger \\ Udo Kreickemeier
}

CESIFo Working PAPER No. 2826

CATEgory 8: TRAde Policy

OCTOBER 2009
An electronic version of the paper may be downloaded
- from the SSRN website:
- from the RePEc website:
- from the CESifo website:
www.SSRN.com
www.RePEc.org
www.CESifo-group.org/wp




\title{
Worker-Specific Effects of Globalisation
}

\begin{abstract}
This paper sets up a general equilibrium model, in which firms are heterogeneous due to productivity differences and workers have fairness preferences and hence provide full effort only if their factor return is sufficiently high. With the wage considered to be fair by workers depending on the operating profits of the firm in which they are employed, more productive firms in this setting are not only larger and make higher profits but they also have to pay higher wages due to rent-sharing. This mechanism leads to wage differentiation even if all workers share the same individual characteristics. We use this framework to study workerspecific effects of trade between two symmetric countries. Exporters in this setting make higher operating profits and hence have to pay higher wages than non-exporters. This exporter wage premium provides a source for losses from trade and, all other things equal, makes a negative employment effect of trade more likely. Furthermore, it contributes significantly to a general increase in intra-group income inequality among production workers when a country moves from autarky to trade.
\end{abstract}

JEL Code: F12, F15, F16.

Keywords: heterogeneous firms, wage inequality, fair wages, involuntary unemployment.

\author{
Hartmut Egger \\ University of Bayreuth \\ Department of Law and Economics \\ Universitaetsstrasse 30 \\ 95447 Bayreuth \\ Germany \\ hartmut.egger@uni-bayreuth.de
}

\author{
Udo Kreickemeier \\ School of Economics \\ University of Nottingham \\ University Park \\ Nottingham NG7 2RD \\ United Kingdom \\ udo.kreickemeier@nottingham.ac.uk
}

September 24, 2009

Kreickemeier gratefully acknowledges financial support from the Leverhulme trust under Programme Grant F114/BF. 


\section{Introduction}

Firm heterogeneity has become an integral part of modern trade theory. With differences between firms arising from exogenous productivity differences, as in Melitz (2003), the key insight from this literature is that trade exhibits substantially different effects on producers at the lower and the upper ends of the technology distribution even within one and the same industry. While the most productive producers benefit from trade liberalisation since they start exporting and hence can serve a larger pool of consumers, the least productive ones are hurt by increasing import competition and have to leave the market. There is broad consensus in the scientific community that these selection effects are a key aspect of trade liberalisation and that they need to be taken seriously in order to provide a better understanding of the channels through which gains from trade can materialise. ${ }^{1}$

The selection effects of international trade go hand in hand with a reallocation of workers within the same sector from less productive to more productive firms. While this effect features prominently in all contributions to the fast-growing literature on trade with heterogeneous firms, in the vast majority of these studies it does not result in workerspecific effects, due to the assumption of a perfect labour market which implies that all firms pay the same wage, and in equilibrium all workers are employed. This is in conflict with considerable evidence from the labour market literature that larger and more productive firms pay higher wages (see Bayard and Troske, 1999; Faggio, Salvanes and Van Reenen, 2007), and hence the assumption of a perfectly competitive labour market seems not be justified empirically (see Hildreth and Oswald, 1997). Therefore, if trade does not affect all firms symmetrically, one should expect it to have worker-specific effects that are linked to firm characteristics. This raises several important questions: Is it better to work for a highly productive firm that expands with liberalisation? What happens to the employees of firms that have to close down due to import competition? How does reallocation of workers across firms affect the wage distribution?

To address these questions we use a variant of the model we developed in Egger and

\footnotetext{
${ }^{1}$ There is also empirical support for these selection effects. See, for instance, Bernard and Jensen (1995, 1999), Clerides, Lach and Tybout (1998) and Schank, Schnabel and Wagner (2007).
} 
Kreickemeier (2009), EK2009 henceforth, in order to illustrate a plausible mechanism that links firm-specific and worker-specific effects of trade. Workers are ex ante identical, but earn different wages due to heterogeneity of firms that arises from productivity differences as in Melitz (2003). Clearly, such wage differentiation is only possible if a labour market imperfection prohibits successful underbidding of wages by outsiders. We consider a fairwage effort mechanism along the lines of Akerlof and Yellen $(1988,1990)$ as source of labour market imperfection in our model. This mechanism is attractive from the perspective of analytical tractability and has strong empirical support (see Howitt, 2002; Bewley, 2005). ${ }^{2}$ The central idea is that workers have fairness preferences and reduce their effort if the firm does not pay a fair wage. The fair wage is a subjective measure and is an increasing function of the profits of the firm in which a worker is employed. This captures a rent-sharing motive of workers that underlies the idea of gift-exchange in the fair-wage effort model (see Fehr and Gächter, 2000; Danthine and Kurmann, 2007) and is well in line with the empirical observation that firms with higher profits pay higher wages (see Blanchflower, Oswald and Sanfey, 1996; Hildreth and Oswald; Arai, 2003). ${ }^{3}$

Trade between identical countries has the standard effect of raising profits of the most productive producers. Due to the rent-sharing motive, workers in these firms see their wages increase relative to the wages paid by non-exporting firms. Since in this model one and the same firm would pay lower wages under non-exporting than under exporting, there exists a pure exporter wage premium. This is a direct implication of the fair-wage effort mechanism, which is well in line with empirical evidence. For instance, Schank, Schnabel and Wagner (2007) show that an exporter wage premium still exists if one rigorously controls for firm and worker characteristics. In the otherwise closely related model developed in EK2009 we choose firm productivity as the firm-internal determinant of the fair wage. Since productivity at the firm level is an exogenous parameter, the relative

\footnotetext{
${ }^{2}$ In a recent book, Akerlof and Shiller (2009) summarize the key advantages of the fair wage-effort model in the following way. "It is an explanation for unemployment that seems to hit the sweet spot. It is simple and realistic, and it also fits the facts" (p. 106).

${ }^{3}$ See Egger and Kreickemeier (2008) for a similar specification of the fair wage constraint in a two-factor model of international trade.
} 
wage of two workers continually employed by two different firms cannot change in the process of globalisation, and an exporter wage premium does not exist in this framework. While the picture that emerges as a consequence of trade liberalisation is therefore not as rich as in the model variant developed here, worker-specific effects of globalisation still exist in EK2009, since there is worker reallocation across firms, and between employment and unemployment.

The focus in this paper is on the worker-specific effect of trade and its consequences for income distribution, while implications on other aggregate variables will be discussed only in passing, because they are already well understood from the analysis in EK2009. There are three other papers that allow for worker-specific effects of trade by modelling inter-firm wage differences in a Melitz-style framework. Similar to us, Amiti and Davis (2008) choose a fair wage-effort model in which the fair wage is an increasing function of profits at the firm level. Their focus is on wage effects of international trade at the firm level. Davis and Harrigan (2007) consider a shirking motive of workers to introduce labour market imperfections into the Melitz framework. While this model also gives rise to wage differentiation if firms differ in their monitoring costs, it cannot explain an exporter wage premium as these costs stay constant when a country moves from autarky to trade. The exporter wage premium is discussed in a recent paper by Helpman, Itskhoki and Redding (2009), who consider search frictions as a source of labour market imperfection. However, in their setting, wage differentiation arises only if workers differ in their abilities. Hence, the respective analysis is complementary to ours.

The remainder of the paper is organised as follows. Section 2 describes the main assumptions and characterises the autarky equilibrium. In section 3, we introduce trade between two symmetric countries and derive the equilibrium in the open economy. This section also presents a comparison between key autarky and trade variables and hence provides insights into both worker-specific and aggregate effects of trade. The last section concludes with a brief summary of the main results. 


\section{Fair wages and heterogeneous firms in the closed economy}

We consider an economy that is populated by $L$ workers and produces two types of goods: differentiated intermediates and a homogeneous final output, with the latter being used as consumption as well as investment good.

\subsection{The model: basics}

Final output $Y$ is a CES aggregate of all available intermediate goods, $q(v)$, and the production technology is given by

$$
Y=\left[M^{-\frac{1}{\sigma}} \int_{v \in V} q(v)^{\frac{\sigma-1}{\sigma}} d v\right]^{\frac{\sigma}{\sigma-1}}
$$

where $\sigma>1$ is the elasticity of substitution between different varieties, and the measure of set $V$ represents the mass of available intermediate goods $M .{ }^{4}$ We impose the standard assumption of perfect competition in the final goods market and choose final output as our numéraire good. This implies that the price for good $Y$ as well as the price index $P$ that corresponds to the CES aggregator in eq. (1) is normalised to one. Profit maximisation of final goods producers results in an isoelastic demand function for each variety of the intermediate good:

$$
q(v)=\frac{Y}{M} p(v)^{-\sigma}
$$

with $p(v)$ representing the price of variety $v$. The intermediate goods sector is populated by a continuum of firms, each producing one unique variety, implying that the mass of available varieties equals the mass of competitors. Furthermore, the intermediate goods market is characterised by monopolistic competition and hence firms take aggregate variables as given, while they set wages as a monopolist in the market for their own variety. In order to produce and distribute their output, firms have to bear a (periodical) fixed cost $f$ in units of final output. In line with Baldwin (2005) we associate these expenditures with local beachhead costs and assume that they are identical for all producers. The output of

\footnotetext{
${ }^{4}$ Using technology (1) instead of the Ethier (1982) technology with external scale economies we exclude those trade effects that are purely due to an increase in market size, which are already well understood.
} 
each firm is linear in labour input $l$ and depends on the firm-specific productivity level $\phi: q=\phi l$. It is notable that $l$ measures labour input in efficiency units, with the efficiency units provided by each employed worker $\varepsilon$ being determined by a fair-wage effort mechanism that is described in detail below.

Profit maximisation of intermediate goods producers leads to the standard result of constant markup pricing, implying that the price set by a firm is proportional to its marginal production $\operatorname{costs} c$ :

$$
p(\phi)=\frac{c(\phi)}{\rho}
$$

with $\rho \equiv(\sigma-1) / \sigma$. In Melitz (2003), we simply have $c(\phi)=1 / \phi$, since all firms pay the same wage, which is normalised to one. In contrast, with labour market imperfections due to a fair-wage effort mechanism wage payments will generally differ across firms, and the same may be true - at least in principle - for the amount of labour efficiency units provided by each worker.

\subsection{The labour market}

The main idea behind the fair-wage effort mechanism is that workers have fairness (or gift exchange) preferences that relate the effort a worker is willing to provide to the ratio between the wage offered by the firm in which he is employed and a reference wage which is subjectively considered to be fair by this worker. The existing literature offers different possibilities for specifying the functional relationship between the effort level and the wage rate. The most commonly used approach is the one suggested by Akerlof and Yellen $(1988,1990)$. They normalise the maximum possible effort provision to one and assume that workers provide full effort if the wage offered by the firm is at least as high as the reference wage. If however the firm offers a wage that falls short of the reference wage, workers reduce their effort proportionally. To put it formally, the functional relationship between effort provision and wages is given by $\varepsilon=\min [w / \hat{w}, 1]$, where $w$ is the wage per worker (not per efficiency unit) and $\hat{w}$ is the reference wage. It is an immediate consequence of the Akerlof and Yellen specification that offering wages which are lower than the fair 
wage does not lower the effective labour costs and hence does not increase profits. Firms are indifferent between all $w \leq \hat{w}$ and hence, we can safely assume that they pay at least the fair reference wage. ${ }^{5}$ Workers in all firms therefore provide full effort $\varepsilon=1$. If firms can hire the profit-maximising number of workers if they set $w=\hat{w}$, this is what they do in equilibrium. Throughout our analysis, we concentrate on a parameter domain which ensures that the fair-wage effort mechanism indeed leads to involuntary unemployment, so that firms will not have to pay a wage that is higher than $\hat{w}$. An explicit condition for this outcome is derived in subsection 2.4.

As extensively discussed in Akerlof (1982) the wage considered to be fair by a worker consists of two components: a firm-internal and a firm-external one. The firm external component is typically associated with a worker's income opportunities outside the present job, which equals the average income of all employed and unemployed workers (see e.g. Kreickemeier and Nelson, 2006). Without unemployment compensation, the external component is given by $(1-U) \bar{w}$, where $1-U$ represents the employment rate and $\bar{w}$ denotes the average factor income of those who have a job. The firm-internal component refers to the firm's profitability and hence may be associated with the notion of rent-sharing (see e.g. Danthine and Kurmann, 2007). In line with Egger and Kreickemeier (2008), EK2008 henceforth, we choose operating profits as a measure of a firm's profitability. Due to constant markup pricing, the operating profits of a firm are proportional to its revenues, and they are given by $r(\phi) / \sigma$. Assuming that the fair wage can be represented by a weighted geometric mean of its two components, and using $w=\hat{w}$ we obtain

$$
w(\phi)=\left(\frac{r(\phi)}{\sigma}\right)^{\theta}[(1-U) \bar{w}]^{1-\theta} .
$$

From (4) it is immediate that firms with higher operating profits pay higher wages. Hence, depending on the firm from which they are hired, workers get a different reward although they are ex ante identical. Clearly, this outcome can be consistent with an equilibrium only if workers who are employed in firms with low operating profits (or who do not have a job at all) cannot successfully underbid wages in firms with high operating profits. As

\footnotetext{
${ }^{5}$ Akerlof and Yellen (1990, p. 272) argue that firms have a slight preference for paying fair wages and thus "when their profits are unaffected by payment of fair wages, they prefer to do so."
} 
in other efficiency wage models, it is the assumption of an information asymmetry that prohibits successful underbidding: Firms and workers cannot sign a binding contract on the effort of workers, and hence any underbidding worker, if hired, would reduce the effort level if he did not receive at least the firm-specific fair wage. Firms know that, and hence have no incentive to accept underbidding from outsiders.

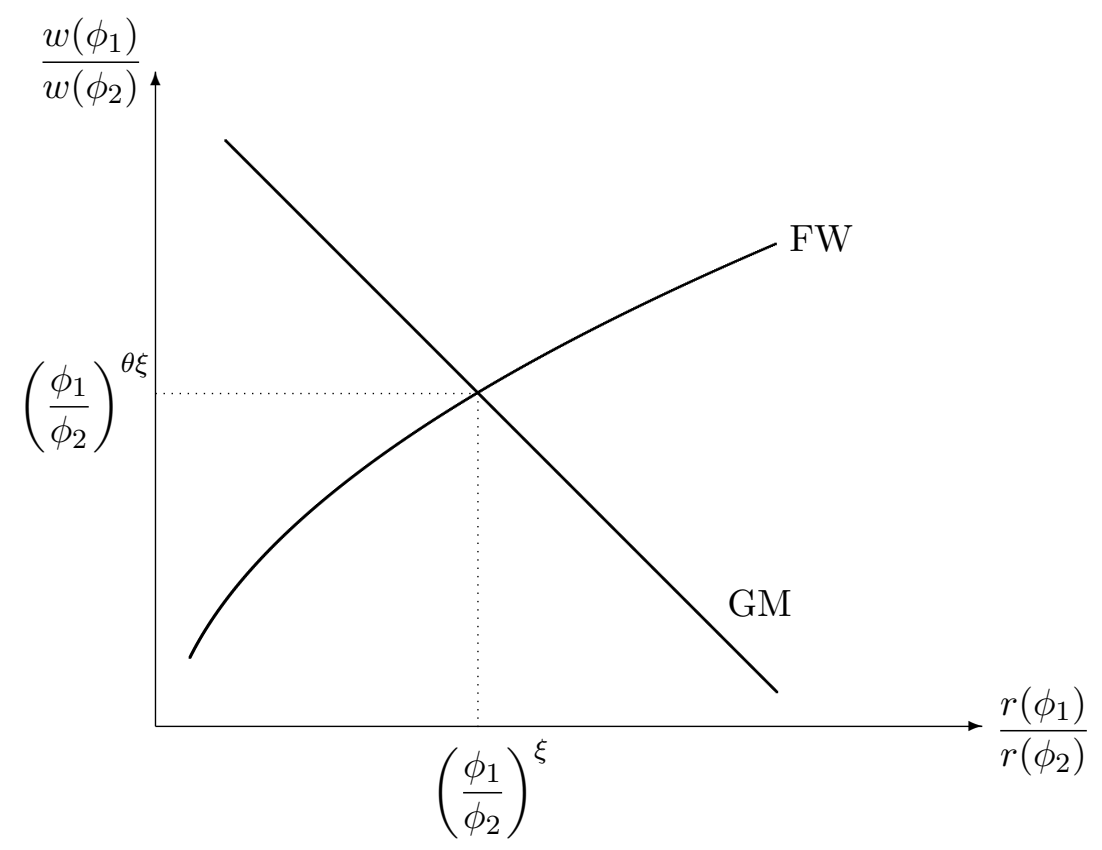

Figure 1: Relative wages and relative revenues

In view of eq. (4), we can now express the relative wage paid by two firms 1 and 2 in terms of their productivities $\phi_{1}$ and $\phi_{2}$. From the fair wage constraint, we immediately get

$$
\frac{w\left(\phi_{1}\right)}{w\left(\phi_{2}\right)}=\left[\frac{r\left(\phi_{1}\right)}{r\left(\phi_{2}\right)}\right]^{\theta} .
$$

There is a second relation between relative wages paid by firms 1 and 2 and their relative domestic revenues, resulting from the goods market equilibrium condition: Higher wages lead to higher marginal cost, ceteris paribus, which imply higher prices and lower revenues. This follows directly from the demand function for intermediates in (2), together with the 
markup-pricing condition (3):

$$
\frac{r\left(\phi_{1}\right)}{r\left(\phi_{2}\right)}=\left[\frac{w\left(\phi_{1}\right)}{w\left(\phi_{2}\right)} \frac{\phi_{2}}{\phi_{1}}\right]^{1-\sigma}
$$

Figure 1 depicts eqs. (5) and (6), where the respective loci are labelled FW and GM for fair wage and goods market, respectively. The resulting relative wage is

$$
\frac{w\left(\phi_{1}\right)}{w\left(\phi_{2}\right)}=\left(\frac{\phi_{1}}{\phi_{2}}\right)^{\theta \xi}
$$

with $\xi \equiv(\sigma-1) /[1+\theta(\sigma-1)]$. Hence, in the closed economy the relative wage paid by two firms 1 and 2 can be expressed as an increasing and concave function of their relative productivities. Since a firm's marginal cost is given by $c(\phi)=w(\phi) / \phi$ we furthermore get

$$
\frac{c\left(\phi_{1}\right)}{c\left(\phi_{2}\right)}=\left(\frac{\phi_{1}}{\phi_{2}}\right)^{\theta \xi-1}
$$

As $\theta \xi<1$, more productive firms have lower marginal cost, but relative to Melitz (2003) the marginal cost profile across firms is flatter, since the higher wage paid by more productive firms mitigates their marginal cost advantage, ceteris paribus.

In complete analogy to Melitz (2003) in our model there is a cutoff productivity $\phi^{*}$ below which firms decide not to produce, implicitly defined by the zero profit condition $\pi\left(\phi^{*}\right)=r\left(\phi^{*}\right) / \sigma-f=0$. It is clear from (7) that the wage paid by the firm with productivity $\phi^{*}, w\left(\phi^{*}\right)$, is the lowest wage paid to workers in the economy. Intuitively, the wage paid by this firm for a given level $\phi^{*}$ depends on the productivity distribution of its competitors. We follow the by now common approach and assume that firm productivities follow a Pareto distribution with the lower bound of productivities normalised to one, yielding cumulative distribution function $G(\phi)=1-\phi^{-k}$.

There is a well-known and immensely useful simplification that follows from assuming a Pareto distribution in a Melitz-type model: The cutoff productivity $\phi^{*}$ is proportional to the average productivity $\tilde{\phi}$, which is implicitly determined by $\pi(\tilde{\phi})=\Pi / M$, implying that the profit of the average firm equals the average profit per firm in the economy, $\bar{\pi}$. In particular, we get:

$$
\tilde{\phi}=\left(\frac{k}{k-\xi}\right)^{\frac{1}{\xi}} \phi^{*}
$$


In order to ensure that the productivity average has a finite positive value, we assume $k>\sigma-1$ (which induces $k>\xi$ for any $\theta$ ) from now on. The wage paid by the marginal firm can then be derived as follows: ${ }^{6}$

$$
w\left(\phi^{*}\right)=\Delta \phi^{*},
$$

with $\Delta \equiv \rho[k /(k-\xi)]^{\frac{1}{\sigma-1}}$. Since the wage paid by the marginal firm is proportional to the cutoff productivity, the marginal cost of the marginal firm, $c\left(\phi^{*}\right)$, is a constant and equal to $\Delta$.

\section{$2.3 \quad$ Firm entry}

In analogy to Melitz (2003), we assume that firm entry involves two types of decisions. First, an unbounded pool of potential entrants decides upon an initial investment of $f_{e}$ units of final output. This investment provides access to a lottery in which firms draw their productivity from the common distribution $G(\phi)$. Each firm has only one draw and the initial investment is sunk. Subsequently, firms decide upon production, conditional on the outcome of the productivity lottery. Starting the production process involves an investment of $f$ units of final output in each period in which the firm remains active. The necessity of non-negative per period profits determines the cutoff productivity level $\phi^{*}$ (see above). In view of (5), (7) and (9), we can rewrite the respective zero cutoff profit condition (ZCP) as follows:

$$
\pi(\tilde{\phi})=\frac{\xi f}{k-\xi}
$$

This implies that profits of the average firm in the market are constant. As discussed in EK2009, this outcome is an immediate consequence of choosing a Pareto specification for parameterising the productivity distribution.

Firms in this model have an infinite horizon and face a common destruction rate, which forces a share $\delta$ of active firms to leave the market in each period. New firms

\footnotetext{
${ }^{6}$ Noting that $Y=M r(\tilde{\phi})$ holds by definition of $\tilde{\phi}$, while $Y=M q(\tilde{\phi})$ follows from (1), we obtain $p(\tilde{\phi})=1$. Together with (3), this implies $w(\tilde{\phi})=\rho \tilde{\phi}$. Accounting for (7) and (9), finally gives (10).
} 
enter the productivity lottery until their expected future profits equal the participation fee. This gives a standard free entry condition $(F E)$. Focussing on steady-state equilibria and abstracting from time discounting, the free entry condition can be expressed $\operatorname{as}^{7}$

$$
\bar{\pi}=\pi(\tilde{\phi})=\left(\phi^{*}\right)^{k} \delta f_{e}
$$

Together, (11) and (12) determine the cutoff productivity level $\phi^{*}$, identical to the one derived in eq. (17) of EK2009. Thereby, the additional condition that $f / f_{e}$ is sufficiently large needs to be imposed in order to ensure that $\phi^{*}>1$.

\subsection{Aggregate variables}

Since free entry of firms drives the expected present value of profits to zero, labour income per worker $(1-U) \bar{w}$ is a suitable (utilitarian) welfare measure. It is easily determined using the fair wage constraint (4) for the marginal firm, as well as (10) and the zero profit condition for the marginal firm, $r\left(\phi^{*}\right) / \sigma=f$ :

$$
(1-U) \bar{w}=\left[\frac{\Delta \phi^{*}}{f^{\theta}}\right]^{\frac{1}{1-\theta}}
$$

Noting that by means of the constant markup pricing rule in (3) a constant share $\rho$ of revenues accrues to workers, aggregate output is proportional to total labour income and hence given by $Y=(1-U) L \bar{w} / \rho$.

Total employment is determined by the adding-up condition that the sum over employment in all firms equals $(1-U) L$. Tedious but straightforward calculations, which are available upon request, yield

$$
1-U=\frac{k-\xi}{k-(1-\theta) \xi}\left[\frac{\Delta \phi^{*}}{f}\right]^{\frac{\theta}{1-\theta}} .
$$

It is easily checked in (14) that unemployment is strictly positive, and hence the fair wageeffort mechanism provides a binding constraint, if $f>\Delta \phi^{*}$. This condition also ensures

\footnotetext{
${ }^{7}$ Notably, a steady state is characterized by the following two conditions. First, the mass of firms newly starting production equals the mass of firms exiting the market due to destruction, $\delta M$. Second, all stock variables, including average productivity and average profits, are constant.
} 
that even the least productive firm offers a wage payment that is higher than the expected labour income: $w\left(\phi^{*}\right)>(1-U) \bar{w}$.

From inspection of (14), two conclusions are immediate. On the one hand, the employment rate, $1-U$, is independent of labour endowment $L$. This is well in line with the empirical observation that involuntary unemployment is a problem which is equally important in large and small economies. On the other hand, the employment rate is positively related to the cutoff productivity level, which suggests that unemployment is less a problem in more advanced economies. To get an intuition for this result, it is useful to note that the bracket term on the right-hand side of (14) is proportional to the ratio of aggregate output and the productivity average: $Y / \tilde{\phi}$. A larger output, $Y$, raises demand for intermediate goods and thereby stimulates employment, all other things equal. A higher productivity average $\tilde{\phi}$ implies that less workers are needed to produce a given level of output. This counteracts the former effect. However, since output $Y$ increases more than propotionally with an increase in $\phi^{*}$, the first effect dominates and employment is stimulated when the cutoff productivity level (and hence the productivity average) goes up. 8

A key feature of our model is the existence of intra-group inequality. One simple aspect of this inequality is captured by the existence of involuntary unemployment, as those who are unemployed earn a lower income than those in a job. In this paper, we have set the income of unemployed workers equal to zero in order to keep the analysis simple. A novel aspect of intra-group inequality which is specific to our setting is that ex ante identical production workers earn different factor returns. This result is particularly

\footnotetext{
${ }^{8}$ Notably, the comparative-static effects of a change in the cutoff productivity level on the employment rate need to be interpreted with care, because these effects are derived under the assumption that $\theta$ and $f$ stay constant. Still, the respective analysis is useful for two reasons. On the one hand, it provides first insights on how trade can affect the employment rate in our setting, which will be useful for our discussion in section 3. On the other hand, the analysis provides insights into the impact of a general productivity growth as reflected by an increase in the lower bound of the productivity distribution, which, in the interest of notational simplicity, has been normalised to one above. From the comparative-static analysis we can conclude that such a technological improvement would lead to a higher employment level in our framework.
} 
notable because the empirical labour literature offers convincing evidence that this form of inequality is substantial and has continuously increased over the last three decades (see Katz and Autor, 1999; Barth and Lucifora, 2006; Autor, Katz and Kearney, 2008).

A simple summary statistics of intra-group inequality that has also been used by EK2009 is given by the ratio of the average wage and the wage paid by the marginal firm, which, in view of $(10),(13)$ and (14), can be written in the following way: ${ }^{9}$

$$
\frac{\bar{w}}{w\left(\phi^{*}\right)}=\frac{k-(1-\theta) \xi}{k-\xi} \equiv \omega
$$

The wage ratio in (15) is larger than one for any $\theta>0$. Intuitively, a higher fairness parameter $\theta$ raises the weight attached to the firm-internal component of the reference wage in the workers' fairness considerations and hence increases intra-group wage inequality, according to (15). This completes our discussion of the closed economy.

\section{The open economy}

In this section, we consider trade between two identical countries whose economies are of the type described above. Trade in final goods is free of any impediments, while international transactions of intermediate goods are subject to two types of trade costs: (i) fixed foreign beachhead costs $f_{x}$ (in units of final output), which must be invested by exporters in each period in order to operate a distribution network in the foreign economy; (ii) variable iceberg trade costs which capture the idea that a fraction of goods melts away en route to foreign consumers. To be more specific, we assume that $\tau>1$ units of the intermediate good must be shipped in order for one unit to arrive in the foreign economy.

\subsection{Exporter selection and wage profile}

As in the two-factor model of EK2008, the home market revenue differential of two firms that have identical productivity but differing export status is jointly determined by

$$
\frac{w^{e}}{w^{n}}=\left[\left(1+\tau^{1-\sigma}\right) \frac{r^{e}}{r^{n}}\right]^{\theta} \quad \text { and } \quad \frac{r^{e}}{r^{n}}=\left(\frac{w^{e}}{w^{n}}\right)^{1-\sigma}
$$

\footnotetext{
${ }^{9}$ For a more sophisticated measure of intra-group inequality, see EK2008.
} 
where superscript $e$ denotes an exporting firm and superscript $n$ denotes a non-exporter. Both equations can be solved to give

$$
\frac{r^{e}}{r^{n}}=\left(1+\tau^{1-\sigma}\right)^{-\theta \xi}<1 \quad \text { and } \quad \frac{w^{e}}{w^{n}}=\left(1+\tau^{1-\sigma}\right)^{\frac{\theta \xi}{\sigma-1}}>1 .
$$

Since exporters have access to a larger pool of consumers, they realise higher operating profits and hence have to pay higher wages than they would pay under non-exporting. This is an immediate consequence of the rent-sharing mechanism that is imposed by our fair-wage effort model. This exporter wage premium lowers revenues in a firm's domestic market as compared to an otherwise identical non-exporting firm. Hence, in contrast to both Melitz (2003) and EK2009 the optimal output decisions of each firm in its (potentially) two markets are interdependent.

When a firm decides between exporting and non-exporting, it compares the extra costs of entering the foreign market - including both the increase in the marginal production costs, due to the existence of an exporter wage premium, and the additional fixed cost expenditures $f_{x}$-with the extra benefits of getting access to a larger pool of consumers. Focussing on the empirically relevant case that only the most productive firms self-select into export status (for which a formal condition will be derived below), the productivity $\phi_{x}^{*}$ of the marginal exporting firm is implicitly determined by the condition that its total profits under exporting and non-exporting are equal

$$
\frac{\left(1+\tau^{1-\sigma}\right) r^{e}\left(\phi_{x}^{*}\right)}{\sigma}-f_{x}=\frac{r^{n}\left(\phi_{x}^{*}\right)}{\sigma} .
$$

The decision problem of firms regarding non-exporting and exporting is illustrated in figure 2 , where $\pi_{t}(\phi)$ refers to total profits. In the case of a non-exporter total profits equal profits from domestic sales, $\pi_{t}^{n}(\phi)=\pi^{n}(\phi)$, while in the case of an exporter, $\pi_{t}^{e}(\phi)$ additionally accounts for export profits. The firm with cutoff productivity $\phi^{*}$ makes zero profits if it sells its products exclusively to the domestic market, while it would make negative profits when serving domestic and foreign consumers. Furthermore, since access to a larger pool of consumers implies that an existing productivity differential between two firms translates into a larger revenue differential under exporting than under non-exporting, the line that represents potential total profits of exporters is steeper than the line for potential total 
profits of non-exporters. Hence, there exists a unique exporter cutoff $\phi_{x}^{*}$, such that firms with $\phi<\phi_{x}^{*}$ stay out of the export market, while firms with $\phi>\phi_{x}^{*}$ make the additional investment $f_{x}$ and serve consumers at home and abroad.

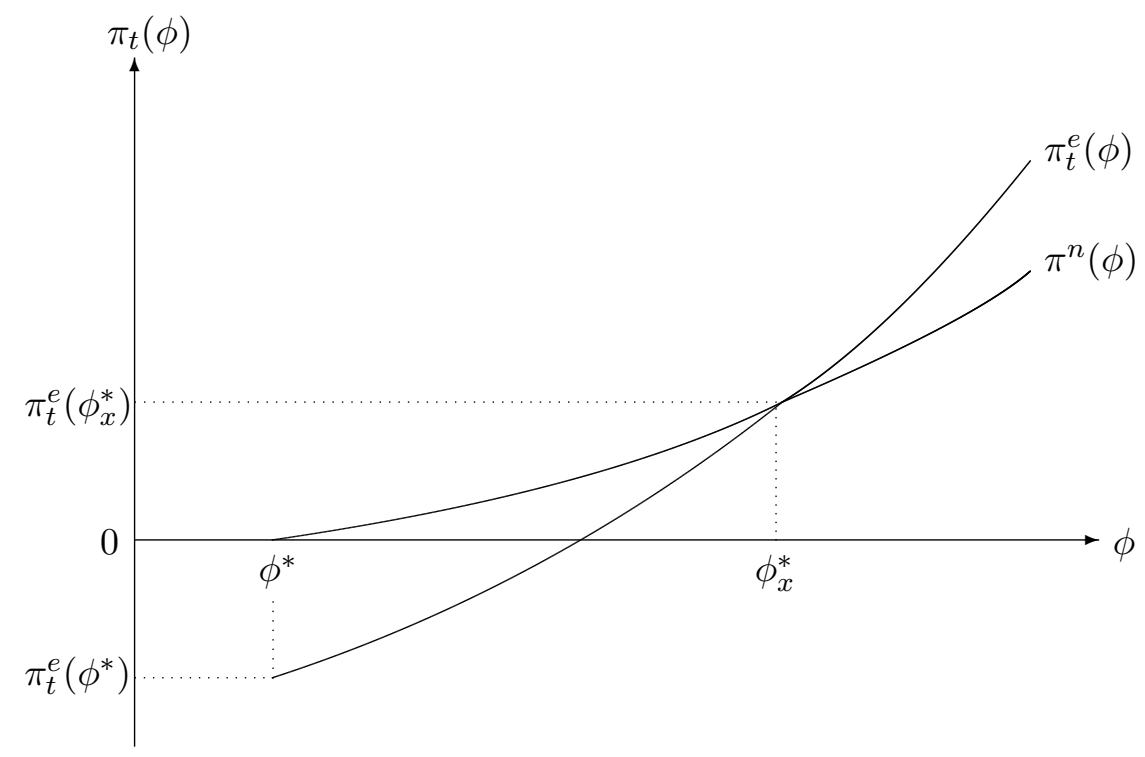

Figure 2: Exporter selection

With Pareto-distributed productivities, we can explicitly solve for the share of exporters in the total mass of firms, which we denote by $\chi$. As in Melitz (2003), we have to assume that fixed and variable export costs are sufficiently large in order to induce self-selection of the most productive forms into export status. As in EK2009 we focus on the case where the fixed export costs are equal to domestic fixed costs, $f_{x}=f$. The share of exporters is then given by

$$
\chi=\left(\frac{\phi^{*}}{\phi_{x}^{*}}\right)^{k}=\left[\left(1+\tau^{1-\sigma}\right)^{\frac{\xi}{\sigma-1}}-1\right]^{\frac{k}{\xi}},
$$

and it can easily be checked that $\chi$ is strictly smaller than 1 for all admissible values of $\tau$. Furthermore, the share of exporters falls if $\tau$ increases.

As noted above, any firm has to pay higher wages under exporting than under nonexporting in order to elicit full effort of its workers. With only the most productive firms self-selecting into exports status, this implies that in the open economy wage payments 
across firms are a discontinuous function of productivity. The impact of productivity differences on wage payments is depicted in figure 3 . The locus $W P^{n}$ represents the wage profile of non-exporters, with the shape of this curve following from our previous observation that the relative wage between any two non-exporters is a positively sloped and concave function of their productivity differential (see eq. (7)). The locus $W P^{e}$ represents the wage profile of exporters. This profile must lie above the $W P^{n}$ locus, due to the existence of a pure exporter wage premium (see eq. (16)). Hence, if only the most productive firms self-select into export status, wage payments shift from profile $W P^{n}$ to profile $W P^{e}$ at $\phi_{x}^{*} / \phi^{*}=\chi^{-1 / k}$.

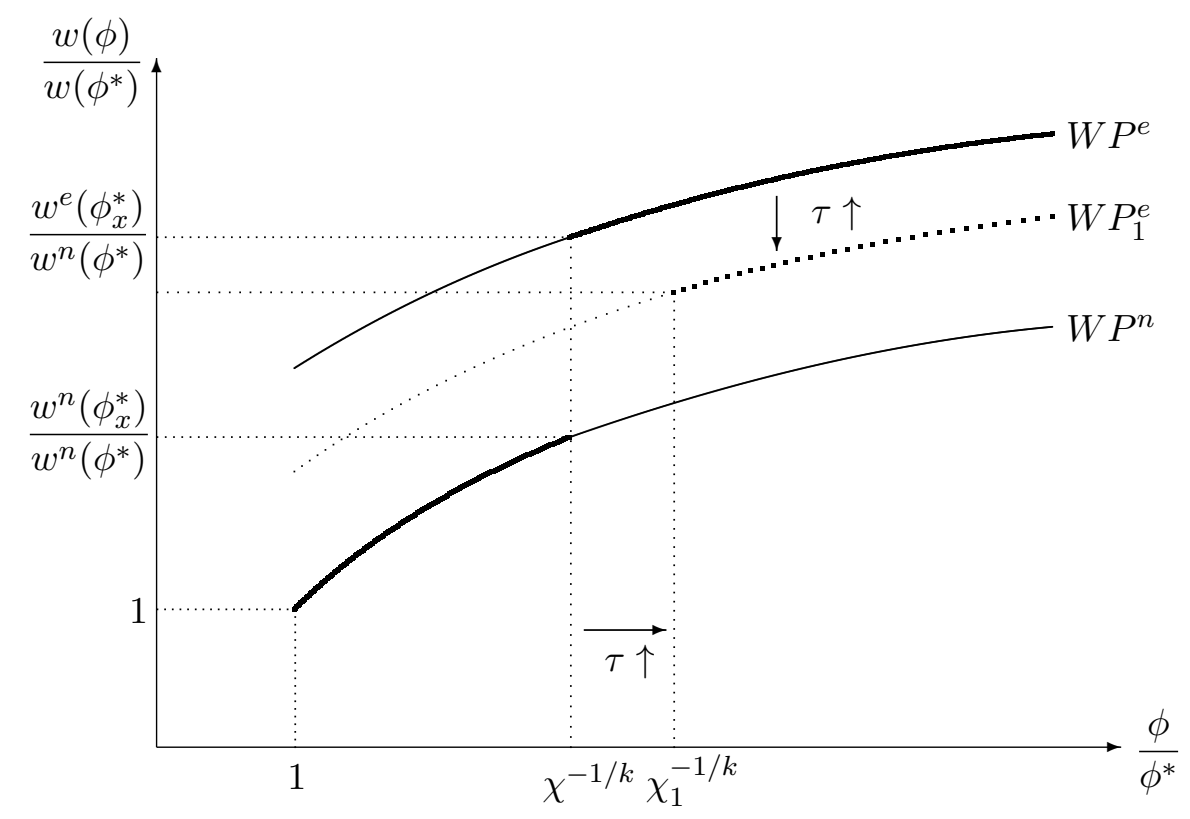

Figure 3: Wage profile

Figure 3 also depicts comparative static effects of changes in $\tau$. An increase in $\tau$ raises the ratio of the two cutoff productivities $\phi_{x}^{*} / \phi^{*}$ and hence lowers the share of exporters from $\chi$ to $\chi_{1}$. At the same time it shifts the $W P^{e}$-locus downwards, according to (16). A deepening of the globalisation process in the form of a reduction in iceberg trade costs not only increases the share of exporters in the total population of firms but also raises 
the exporter wage premium.

\subsection{Characterisation of the average producer}

To solve for the trade equilibrium, we define the average productivity of all firms selling to the market, which in the case of the open economy include the exporters of the respective other country. Defining such an average for the open economy is potentially more complicated than in EK2009, because in the setting considered here firms pay wages from different profiles, depending on whether they are exporters or non-exporters (see figure 3). Hence, we first need to fix the export status of the average firm, in order to determine the relevant wage profile for this producer. This is an arbitrary decision, and without loss of generality we associate the average firm with a non-exporter. Noting that $M_{t} \equiv(1+\chi) M$ firms (including domestic producers and foreign exporters) sell their products in each market, we choose the productivity average, $\tilde{\phi}_{t}$, such that $\Pi_{t}=M_{t} \pi_{t}^{n}\left(\tilde{\phi}_{t}\right)$ holds, with $\Pi_{t}$ representing aggregate profits in either country under openness and $\pi_{t}^{n}\left(\tilde{\phi}_{t}\right) \equiv r^{n}\left(\tilde{\phi}_{t}\right) / \sigma-f$ denote profits of the average firm.

The derivation of $\tilde{\phi}_{t}$ is shown in detail in EK2008. Since we have assumed $f=f_{x}$, the analysis simplifies enormously, and we get

$$
\tilde{\phi}_{t}=\left(\frac{k}{k-\xi}\right)^{\frac{1}{\xi}} \phi^{*} .
$$

Compared to (9), $\tilde{\phi}_{t}$ replaces $\tilde{\phi}$ in (19), but otherwise both equations are identical. This implies that the productivity average in the open economy is higher than in autarky if and only if the cutoff productivity $\phi^{*}$ is higher.

As in the closed economy, $\phi^{*}$ is determined by the zero cutoff profit condition and the free entry condition. Again, the mechanism is standard for a model of the Melitztype: Profits per firm, which are given by $\bar{\pi}_{t} \equiv \Pi_{t} / M$, are higher in the open economy, which makes entry in the productivity lottery more attractive, ceteris paribus. In order to restore equilibrium, this has to be balanced by an increase in the cutoff productivity, which by itself makes entry into the productivity less attractive. With Pareto-distributed productivities we find the explicit solution $\phi^{*}=(1+\chi)^{1 / k} \phi_{a}^{*}$, where subscript $a$ refers to 
the autarky scenario. As a consequence, our model reproduces the key insight from Melitz (2003) that the least productive firms exit the market when a country opens up for trade.

\subsection{Welfare, unemployment and income distribution}

With the productivity average at hand, we can now determine the key aggregate variables in the open economy and compare them with their counterparts under autarky. As in the closed economy, we can use labour income per worker as a utilitarian welfare measure, and we get

$$
(1-U) \bar{w}=[(1-U) \bar{w}]_{a}\left(\frac{\phi^{*}}{\phi_{a}^{*}}\right)^{\frac{1}{1-\theta}}
$$

Since the cutoff productivity is higher in the open economy, as shown in the previous section, international trade leads to aggregate gains. ${ }^{10}$ Notably, aggregate labour income - and therefore aggregate output - increases more than proportionally with the cutoff productivity.

Adding up employment levels over all firms and dividing the respective expression by the total labour force $L$ gives the employment rate

$$
1-U=\left(1-U_{a}\right)\left(\frac{\phi^{*}}{\phi_{a}^{*}}\right)^{\frac{\theta}{1-\theta}} \frac{\Gamma}{1+\chi},
$$

with $\Gamma=\Gamma(\tau, k, \theta, \sigma)$ being a constant that is strictly smaller than $1+\chi{ }^{11}$ Comparing (14) and (21), we can distinguish two channels through which trade affects employment in our setting. On the one hand, it leads to an increase in the cutoff productivity. Since, as shown above, aggregate output increases more than proportionally with $\phi^{*}$, this effect increases employment, ceteris paribus. On the other hand, exporting induces higher wage payments and hence a cost-penalty, which, all other things equal, makes the labour market imperfection more severe. This effect is reinforced by the existence of trade costs, which renders firms less competitive in their export markets and hence provides an additional

\footnotetext{
${ }^{10} \mathrm{As}$ in EK2009, losses from trade are possible if $f_{x}$ is sufficiently small relative to $f$, and therefore the selection effect of trade is weak. But note that by assuming production technology (1), which excludes the standard "love of variety" effect, we have eliminated one potential source of gains from trade.

${ }^{11}$ An explicit solution for $\Gamma$ is provided in eq. (40) of EK2008.
} 
source for efficiency loss. Both of these effects lower employment, ceteris paribus. This is captured by variable $\Gamma$ and the fact that this variable is smaller than $1+\chi$. In general, it is not clear which of the two effects dominates. However, one can show that employment is lower in the open economy than under autarky if the rent-sharing parameter $\theta$ is small, while trade stimulates employment if $\theta$ is sufficiently large. This result differs from insights in EK2009, where in the case of $f=f_{x}$ employment is always smaller in the open economy than under autarky.

The final variable we need to determine is intra-group wage inequality, which in the open economy is given by

$$
\omega=\omega_{a} \frac{1+\chi}{\Gamma} .
$$

From (15) and (22), we can conclude that trade definitely increases intra-group inequality among production workers. As pointed out by EK2009 this result provides an explanation for the empirical observation that intra-group inequality and international trade (in particular in the form of intermediate goods transactions) have simultaneously increased over the last three decades. In their paper it is a mere compositional effect that is responsible for the respective impact of trade on intra-group inequality. More workers are employed in the productive firms as these firms expand production due to access to the export market. This dominates the counteracting effect of the least productive firms exiting the market which, ceteris paribus, reduces intra-group inequality.

Our paper goes one step further and emphasises the role of worker-specific effects of globalisation in a setting that takes the rent-sharing motive in the gift exchange between firms and workers serious and allows for an exporter wage premium. This links the discussion on intra-group wage inequality to the recent empirical literature on the performance of heterogeneous firms in an international context. This literature finds conclusive evidence for more productive firms being exporters and for exporters paying a wage premium that cannot be fully explained by productivity differences (or other observable differences) between exporters and non-exporters (see Schank, Schnabel and Wagner, 2007).

While our previous discussion makes clear that there are gains from trade in our setting, which are however not equally distributed among all workers, it does not provide 
insights into a core question of international trade theory: Do all workers experience a wage increase in absolute terms when a country opens up for trade or are there workers who need to be compensated for their losses? To answer this question, we can distinguish two groups of individuals: those who remain employed in the same firm when a country opens up for trade and those who switch their employment status. ${ }^{12}$

Regarding the first group of workers, we know from above that the existence of a pure exporter wage premium implies that workers in exporting firms benefit more than proportional from the openening up of a country. However, what about those who remain employed by a non-exporter? There are two effects, working in opposite directions. On the one hand, labour income per worker increases, which improves outside income opportunities and hence raises the wage considered to be fair by workers, ceteris paribus. On the other hand, operating profits of non-exporters decline, which induces exit of the least productive firms and reduces the wage considered to be fair by workers, due to a rent-sharing mechanism. In EK2009, only the first effect is present, since the firm-specific determinant of the fair wage is exogenous. By contrast, in Amiti and Davis (2008) only the second effect is present, since the firm-external determinant is exogenous. In our analysis, both of these effects interact in a non-trivial way. It turns out that with $f=f_{x}$, as assumed, the positive firm-external effect is always dominant: In view of the fair wage specification in eq. (4) we can calculate

$$
\frac{w^{n}(\phi)}{w_{a}(\phi)}=\left(\frac{(1-U) \bar{w}}{[(1-U) \bar{w}]_{a}}\right)^{\frac{(1-\theta) \xi}{\sigma-1}}
$$

and hence $w^{n}(\phi)>w_{a}(\phi)$ follows from (20). This implies that trade exhibits a lifting-allboats effect, with a positive impact on wages in all firms.

In contrast to Melitz (2003), where a lifting-all-boats effect also exists, this however does not mean that trade necessarily renders all workers better off. The reason is that trade triggers relocation of labour and hence leads to a switch in the employment status of at least some workers. To be more specific, there is relocation of labour from less to

\footnotetext{
${ }^{12}$ In the following discussion, we ignore those changes in the employment status of workers that are merely due to the ongoing replacement of incumbent firms by new entrants in the dynamic setting under consideration.
} 
more productive firms, which definitely raises income and hence welfare of these workers. However, as noted in the last paragraph trade also triggers a change in aggregate employment. To the extent that employment falls, there definitely exists a subgroup of workers which is worse off in the open economy, while the opening up for trade may render all workers better off (and hence give rise to a Pareto improvement) if aggregate employment increases.

\section{Concluding remarks}

In this paper, we construct a simple general equilibrium model with heterogeneous firms and fairness preferences of workers as a source of labour market imperfection. With operating profits serving as a firm-internal component of the fair wage, which has to be paid by firms in order to elicit full effort of workers, this framework gives rise to a simple rent-sharing mechanism that generates firm-specific wages and leads to intra-group inequality among ex ante identical production workers. The link between product and labour market performance in this model is well in line with the empirical observation that more productive firms are larger, make higher profits and pay higher wages. Extending the theoretical framework to one with trade between two identical economies, we show that trade has important worker-specific effects. Most notably, exporting provides access to a larger pool of consumers and hence leads to higher operating profits. Due to a rent-sharing mechanism, this generates a pure exporter wage premium.

With selection of only the best firms into export status, a movement from autarky to trade is typically associated with welfare gains, while the employment effects are not clear in general. The existence of a pure exporter wage premium introduces a new source of losses from trade and, all other things equal, lowers employment in the open economy. Furthermore, it raises intra-group wage inequality and hence contributes to our understanding why both intra-group inequality and international trade have simultaneously increased over the last three decades.

In contrast to our closely related analysis in EK2009, in which for simplicity we used (exogenous) productivity as the firm-internal component of the fair wage, in the current 
model the relative wage of two workers employed in different firms changes if these two firms have a different export status. We can therefore show how worker-specific effects are jointly determined by firm-specific wage effects that differ for exporters and nonexporters, and by the reallocation of workers between firms as well as between employment and unemployment. One limitation the current paper shares with EK2009 and all other models that build on the framework of Melitz (2003) is that there is only a single factor of production, and therefore all inequality is intra-group by construction. In EK2008 we have developed a two-factor model that remedies this shortcoming. The framework features a combination of intra-group and inter-group inequality and thereby presents a more comprehensive picture of the distributional effects of international trade.

\section{References}

Akerlof, G. A. (1982), 'Labor Contracts as Partial Gift Exchange', Quarterly Journal of Economics, 97, 543-569.

Akerlof, G. A. and R. J. Shiller (2009), Animal Spirits (Princeton: Princeton University Press).

Akerlof, G. A. and J. L. Yellen (1988), 'Fairness and Unemployment', American Economic Review, 78, 44-49.

Akerlof, G. A. and J. L. Yellen (1990), 'The Fair Wage-Effort Hypothesis and Unemployment', Quarterly Journal of Economics, 105, 255-283.

Amiti, M. and D. R. Davis (2008), 'Trade, Firms, and Wages: Theory and Evidence', NBER Working Paper 14106.

Arai, M. (2003), 'Wages, Profits and Capital-Intensity: Evidence from Matched WorkerFirm Data', Journal of Labor Economics, 21, 593-618.

Autor, D. H., L. F. Katz and M. F. Kearney (2008), 'Trends in U.S. Wage Inequality: Revising the Revisionists', Review of Economics and Statistics, 90, 300-323. 
Baldwin, R. (2005), 'Heterogeneous Firms and Trade: Testable and Untestable Properties of the Melitz Model', NBER Working Paper 11471.

Barth, E. and C. Lucifora (2006), 'Wage Dispersion, Markets and Institutions: The Effects of the Boom in Education on the Wage Structure', IZA Discussion Paper 2181.

Bayard, K. and K. R. Troske (1999), 'Examining the Employer-Size Wage Premium in the Manufacturing, Retail Trade, and Service Industries Using Employer-Employee Matched Data', American Economic Review, 89, 99-103.

Bernard, A. B. and J. B. Jensen (1995), 'Exporters, Jobs, and Wages in U.S. Manufacturing: 1976-1987', Brookings Papers on Economic Activity. Microeconomics, 67119 .

Bernard, A. B. and J. B. Jensen (1999), 'Exceptional Exporter Performance: Cause, Effect, or Both?', Journal of International Economics, 47, 1-25.

Bewley, T. (2005), 'Fairness, Reciprocity, and Wage Rigidity', in: H. Gintis, S. Bowles, R. Boyd and E. Fehr (eds.), Moral Sentiments and Material Interests: The Foundations of Cooperation in Economic Life (Cambridge/Mass.: MIT Press), 303-338.

Blanchflower, D.G., A.J. Oswald and Sanfey, P. (1996), 'Wages, Profits, and Rentsharing', Quarterly Journal of Economics, 111, 227-251.

Clerides, S. K., S. Lach and J.R. Tybout (1998), 'Is Learning by Exporting Important? Micro-Dynamic Evidence from Colombia, Mexico, and Morocco', Quarterly Journal of Economics, 113, 903-947.

Danthine, J. P. and A. Kurmann (2007), 'The Macroeconomic Consequences of Reciprocity in Labor Relations', Scandinavian Journal of Economics, 109, 857-881.

Davis, D. R. and J. Harrigan (2007), 'Good Jobs, Bad Jobs, and Trade Liberalization', NBER Working Paper 13139. 
Egger, H. and U. Kreickemeier (2008), 'Fairness, Trade, and Inequality', CESifo Working Paper 2344.

Egger, H. and U. Kreickemeier (2009), 'Firm Heterogeneity and the Labor Market Effects of Trade Liberalization', International Economic Review, 50, 187-216.

Ethier, W. J. (1982), 'National and International Returns to Scale in the Modern Theory of International Trade', American Economic Review, 72, 389-405.

Faggio, G., K. Salvanes and J. Van Reenen (2007), 'The Evolution of Inequality in Productivity and Wages: Panel Data Evidence', NBER Working Paper 13351.

Fehr, E. and S. Gächter (2000), 'Fairness and Retaliation: The Economics of Reciprocity', Journal of Economic Perspectives, 14, 159-181.

Helpman, E., O. Itskhoki and S. Redding (2009), 'Inequality and Unemployment in a Global Economy', NBER Working Paper 14478.

Hildreth, A. K. G. and A. J. Oswald (1997), 'Rent-Sharing and Wages: Evidence from Company and Establishment Panels', Journal of Labor Economics, 15, 318-337.

Howitt, P. (2002), 'Looking Inside the Labor Market: A Review Article', Journal of Economic Literature, 40, 125-138.

Katz, L. F. and D. H. Autor (1999), 'Changes in the Wage Structure and Earnings Inequality', in: O. Ashenfelter and D. Card (eds.), Handbook of Labor Economics, Vol. $3 A$ (Amsterdam: Elsevier), 1463-1555.

Kreickemeier, U. and D. R. Nelson (2006), 'Fair Wages, Unemployment and Technological Change in a Global Economy', Journal of International Economics, 70, 451-469.

Melitz, M. J. (2003), 'The Impact of Trade on Intra-Industry Reallocations and Aggregate Industry Productivity', Econometrica, 71, 1695-1725. 
Schank, T., C. Schnabel and J. Wagner (2007), 'Do Exporters Really Pay Higher Wages? First Evidence from German Linked Employer-Employee Data', Journal of International Economics, 72, 52-74. 


\section{CESifo Working Paper Series}

for full list see www.cesifo-group.org/wp

(address: Poschingerstr. 5, 81679 Munich, Germany, office@cesifo.de)

2765 Pierre M. Picard and David E. Wildasin, Labor Market Pooling, Outsourcing and Labor Contracts, August 2009

2766 Stefan Voigt and Lorenz Blume, The Economic Effects of Federalism and Decentralization - A Cross-Country Assessment, August 2009

2767 David S. Jacks, Christopher M. Meissner and Dennis Novy, Trade Booms, Trade Busts, and Trade Costs, August 2009

2768 Mario Jametti and Thomas von Ungern-Sternberg, Hurricane Insurance in Florida, August 2009

2769 Alessandro Balestrino, Kind of Black: The Musicians' Labour Market in Italy, August 2009

2770 Yosr Abid Fourati and Cathal O’Donoghue, Eliciting Individual Preferences for Pension Reform, August 2009

2771 Christian Breuer and Chang Woon Nam, VAT on Intra-Community Trade and Bilateral Micro Revenue Clearing in the EU, August 2009

2772 Choudhry Tanveer Shehzad, Jakob De Haan and Bert Scholtens, Growth and Earnings Persistence in Banking Firms: A Dynamic Panel Investigation, August 2009

2773 Erdal Yalcin, Uncertain Productivity Growth and the Choice between FDI and Export, August 2009

2774 Klaus Abberger, Wolfgang Nierhaus and Shynar Shaikh, Findings of the Signal Approach for Financial Monitoring in Kazakhstan, September 2009

2775 Sascha O. Becker, Francesco Cinnirella and Ludger Woessmann, The Trade-off between Fertility and Education: Evidence from before the Demographic Transition, September 2009

2776 Thomas Aronsson and Erkki Koskela, Optimal Income Taxation, Outsourcing and Policy Cooperation in a Dynamic Economy, September 2009

2777 Joel Slemrod, Old George Orwell Got it Backward: Some Thoughts on Behavioral Tax Economics, September 2009

2778 Cagri Seda Kumru and Athanasios C. Thanopoulos, Social Security Reform and Temptation, September 2009 
2779 Alessandro Bucciol and Roel M. W. J. Beetsma, Inter- and Intra-generational Consequences of Pension Buffer Policy under Demographic, Financial and Economic Shocks, September 2009

2780 Eduardo Strube and Marcelo Resende, Complementarity of Innovation Policies in the Brazilian Industry: An Econometric Study, September 2009

2781 Henry Tulkens and Vincent van Steenberghe, "Mitigation, Adaptation, Suffering": In Search of the Right Mix in the Face of Climate Change, September 2009

2782 Maria L. Loureiro, Anna Sanz-de-Galdeano and Daniela Vuri, Smoking Habits: Like Father, Like Son, Like Mother, Like Daughter, September 2009

2783 Momi Dahan, Tehila Kogut and Moshe Shalem, Do Economic Policymakers Practice what they Preach? The Case of Pension Decisions, September 2009

2784 Eytan Sheshinski, Uncertain Longevity and Investment in Education, September 2009

2785 Nannette Lindenberg and Frank Westermann, How Strong is the Case for Dollarization in Costa Rica? A Note on the Business Cycle Comovements with the United States, September 2009

2786 Leif Danziger, Noncompliance and the Effects of the Minimum Wage on Hours and Welfare in Competitive Labor Markets, September 2009

2787 Gerlinde Fellner, Rupert Sausgruber and Christian Traxler, Testing Enforcement Strategies in the Field: Legal Threat, Moral Appeal and Social Information, September 2009

2788 Gabriel J. Felbermayr, Mario Larch and Wolfgang Lechthaler, Unemployment in an Interdependent World, September 2009

2789 Sebastian G. Kessing, Federalism and Accountability with Distorted Election Choices, September 2009

2790 Daniel Gros, Global Welfare Implications of Carbon Border Taxes, September 2009

2791 Louis N. Christofides, Michael Hoy and Ling Yang, The Gender Imbalance in Participation in Canadian Universities (1977-2005), September 2009

2792 Jan K. Brueckner and Robert W. Helsley, Sprawl and Blight, September 2009

2793 Vidar Christiansen and Stephen Smith, Externality-correcting Taxes and Regulation, September 2009

2794 John Beirne, Guglielmo Maria Caporale, Marianne Schulze-Ghattas and Nicola Spagnolo, Global and Regional Spillovers in Emerging Stock Markets: A Multivariate GARCH-in-mean Analysis, September 2009 
2795 Rüdiger Pethig and Frieder Kolleß, Asymmetric Capital-Tax Competition, Unemployment and Losses from Capital Market Integration, September 2009

2796 Ngo Van Long, Horst Raff and Frank Stähler, Innovation and Trade with Heterogeneous Firms, September 2009

2797 Margit Osterloh and Bruno S. Frey, Research Governance in Academia: Are there Alternatives to Academic Rankings?, September 2009

2798 Thiess Buettner and Clemens Fuest, The Role of the Corporate Income Tax as an Automatic Stabilizer, September 2009

2799 Annette Alstadsæter, Measuring the Consumption Value of Higher Education, September 2009

2800 Peter Friedrich, Chang Woon Nam and Janno Reiljan, Local Fiscal Equalization in Estonia: Is a Reform Necessary?, September 2009

2801 Evžen Kočenda and Jan Hanousek, State Ownership and Control in the Czech Republic, September 2009

2802 Michael Stimmelmayr, Wage Inequality in Germany: Disentangling Demand and Supply Effects, September 2009

2803 Biswa N. Bhattacharyay, Towards a Macroprudential Surveillance and Remedial Policy Formulation System for Monitoring Financial Crisis, September 2009

2804 Margarita Katsimi, Sarantis Kalyvitis and Thomas Moutos, "Unwarranted" Wage Changes and the Return on Capital, September 2009

2805 Christian Lessmann and Gunther Markwardt, Aid, Growth and Devolution, September 2009

2806 Bas Jacobs and Dirk Schindler, On the Desirability of Taxing Capital Income to Reduce Moral Hazard in Social Insurance, September 2009

2807 Hans Gersbach and Noemi Hummel, Climate Policy and Development, September 2009

2808 David E. Wildasin, Fiscal Competition for Imperfectly-Mobile Labor and Capital: A Comparative Dynamic Analysis, September 2009

2809 Johan Eyckmans and Cathrine Hagem, The European Union's Potential for Strategic Emissions Trading through Minimal Permit Sale Contracts, September 2009

2810 Ruediger Bachmann and Christian Bayer, The Cross-section of Firms over the Business Cycle: New Facts and a DSGE Exploration, October 2009

2811 Slobodan Djajić and Michael S. Michael, Temporary Migration Policies and Welfare of the Host and Source Countries: A Game-Theoretic Approach, October 2009 
2812 Devis Geron, Social Security Incidence under Uncertainty Assessing Italian Reforms, October 2009

2813 Max-Stephan Schulze and Nikolaus Wolf, Economic Nationalism and Economic Integration: The Austro-Hungarian Empire in the Late Nineteenth Century, October 2009

2814 Emilia Simeonova, Out of Sight, Out of Mind? The Impact of Natural Disasters on Pregnancy Outcomes, October 2009

2815 Dan Kovenock and Brian Roberson, Non-Partisan 'Get-Out-the-Vote' Efforts and Policy Outcomes, October 2009

2816 Sascha O. Becker, Erik Hornung and Ludger Woessmann, Catch Me If You Can: Education and Catch-up in the Industrial Revolution, October 2009

2817 Horst Raff and Nicolas Schmitt, Imports, Pass-Through, and the Structure of Retail Markets, October 2009

2818 Paul De Grauwe and Daniel Gros, A New Two-Pillar Strategy for the ECB, October 2009

2819 Guglielmo Maria Caporale, Thouraya Hadj Amor and Christophe Rault, International Financial Integration and Real Exchange Rate Long-Run Dynamics in Emerging Countries: Some Panel Evidence, October 2009

2820 Saša Žiković and Randall K. Filer, Hybrid Historical Simulation VaR and ES: Performance in Developed and Emerging Markets, October 2009

2821 Panu Poutvaara and Andreas Wagener, The Political Economy of Conscription, October 2009

2822 Steinar Holden and Åsa Rosén, Discrimination and Employment Protection, October 2009

2823 David G. Mayes, Banking Crisis Resolution Policy - Lessons from Recent Experience Which elements are needed for robust and efficient crisis resolution?, October 2009

2824 Christoph A. Schaltegger, Frank Somogyi and Jan-Egbert Sturm, Tax Competition and Income Sorting: Evidence from the Zurich Metropolitan Area, October 2009

2825 Natasa Bilkic, Thomas Gries and Margarethe Pilichowski, Stay in School or Start Working? - The Human Capital Investment Decision under Uncertainty and Irreversibility, October 2009

2826 Hartmut Egger and Udo Kreickemeier, Worker-Specific Effects of Globalisation, October 2009 